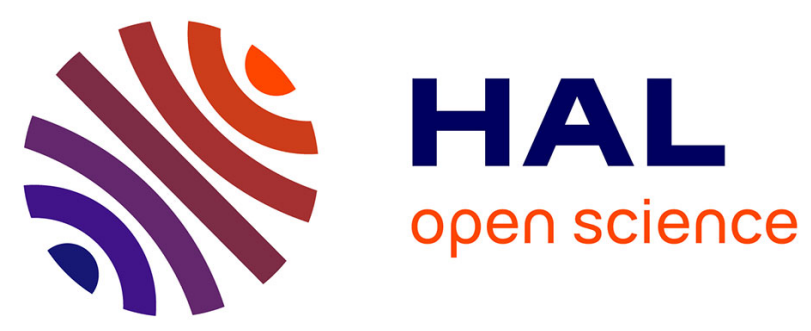

\title{
Enantioselective Organocatalyzed Michael Additions of Nitroalkanes to 4-Arylidenedihydrofuran-2,3-diones and 4-Arylidenepyrrolidine-2,3-diones
}

\author{
Mouhamadou Fofana, Yohan Dudognon, Laura Bertrand, Thierry \\ Constantieux, Jean Rodriguez, Ibrahima Ndiaye, Damien Bonne, Xavier \\ Bugaut
}

\section{To cite this version:}

Mouhamadou Fofana, Yohan Dudognon, Laura Bertrand, Thierry Constantieux, Jean Rodriguez, et al.. Enantioselective Organocatalyzed Michael Additions of Nitroalkanes to 4-Arylidenedihydrofuran2,3-diones and 4-Arylidenepyrrolidine-2,3-diones. European Journal of Organic Chemistry, 2020, 2020 (23), pp.3486 - 3490. 10.1002/ejoc.202000460 . hal-03163964

\section{HAL Id: hal-03163964 https://hal.science/hal-03163964}

Submitted on 9 Mar 2021

HAL is a multi-disciplinary open access archive for the deposit and dissemination of scientific research documents, whether they are published or not. The documents may come from teaching and research institutions in France or abroad, or from public or private research centers.
L'archive ouverte pluridisciplinaire HAL, est destinée au dépôt et à la diffusion de documents scientifiques de niveau recherche, publiés ou non, émanant des établissements d'enseignement et de recherche français ou étrangers, des laboratoires publics ou privés. 


\title{
Enantioselective Organocatalyzed Michael Additions of Nitroalkanes to 4-Arylidenedihydrofuran-2,3-diones and 4-Arylidenepyrrolidine-2,3-diones
}

\author{
Mouhamadou Fofana, ${ }^{[\mathrm{a}, \mathrm{b}]}$ Yohan Dudognon, ${ }^{[\mathrm{a}]}$ Laura Bertrand, ${ }^{[\mathrm{a}]}$ Thierry Constantieux, ${ }^{[\mathrm{a}]}$ \\ Jean Rodriguez, ${ }^{[a]}$ Ibrahima Ndiaye, ${ }^{[b]}$ Damien Bonne ${ }^{*[a]}$ and Xavier Bugaut ${ }^{*[a]}$
}

Abstract: Tremendous efforts have been devoted to the development of organocatalytic enantioselective Michael additions of nitroalkanes to $\alpha, \beta$-unsaturated carbonyl compounds. However, using highly substituted electrophiles remain challenging, since the additional substituents decrease the electrophilicity. $\beta$-Arylidene- $\alpha$-ketolactones and $\alpha$-ketolactams are used as highly electrophilic Michael acceptors that afford the corresponding products in moderate to good yields, with high enantioselectivities. This success relies on their rigid structure that prevents deconjugation and the efficient recognition of the $\alpha$-dicarbonyl motif by the hydrogen-bond donor catalyst.
Michael additions are among the most versatile transformations in the toolbox of synthetic organic chemists. ${ }^{[1]}$ The reaction course often implies the creation of one or several stereogenic centers, and a plethora of studies have been devoted to the control of their absolute configurations, with organocatalysis as the most successful method. ${ }^{[2]}$ Among Michael additions, the reaction between nitroalkanes and $\alpha, \beta$-unsaturated carbonyl compounds is especially appealing. This is due to the possibilities offered to the catalysts to create specific interactions to induce enantioselectivity and the polyfunctional nature of the products. ${ }^{[3,4]}$ Indeed, the nitro and carbonyl functionalities can be chemoselectively proceeded to deliver valuable enantioenriched compounds such as pyrrolidines ${ }^{[5]}$ or $\gamma$-amino alcohols. ${ }^{[6]}$

However, a limitation of this transformation is attained when highly substituted Michael acceptors are used. Indeed, additional substituents, especially at the $\alpha$ position, are deleterious to the reactivity because of unfavorable steric interactions that tend to hamper the conjugation between the olefin and the electron-withdrawing group (Scheme 1, Equation 1). ${ }^{[7]} \mathrm{A}$ first solution to tackle this problem is to add a second electronwithdrawing group either at the $\alpha$ or at the $\beta$ position to increase the electrophilicity (Scheme 1, Equation 2) ${ }^{[8-10]}$ It is also

[a] Dr. M. Fofana, Dr. Y. Dudognon, L. Bertrand, Prof. Dr. T. Constantieux, Prof. Dr. J. Rodriguez, Dr. D. Bonne, Dr. X. Bugaut Aix Marseille Univ, CNRS, Centrale Marseille, ISM2, Marseille, France

E-mail: damien.bonne@univ-amu.fr,xavier.bugaut@univ-amu.fr https://ism2.univ-amu.fr/fr/annuaire/stereo/bonnedamien https://ism2.univ-amu.fr/fr/annuaire/stereo/bugautxavier

[b] Dr. M. Fofana, Prof. Dr. I. Ndiaye

Département de Chimie, Faculté des Sciences et Techniques, Université Cheikh Anta Diop possible to tether the nucleophile to render the reaction intramolecular so that the favorable entropic factor overcomes the

(Eq 1) $\alpha, \beta$-disubstituted Michael acceptors are challenging substrates ${ }^{[7]}$<smiles></smiles><smiles>[R]C(C([R])[C@@H]([R])[N+](=O)[O-])[C@H]([R7])[N+](=O)[O-]</smiles>

(Eq 2) Additional EWG at $\alpha$ - and/or $\beta$-position ${ }^{[8,9,10]}$

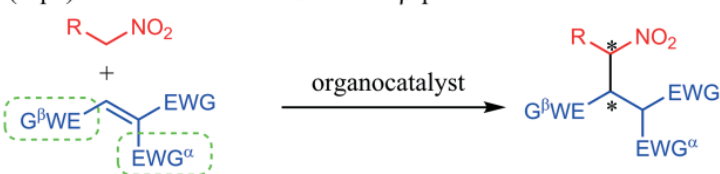

(Eq 3) Intramolecular reactions ${ }^{[11]}$

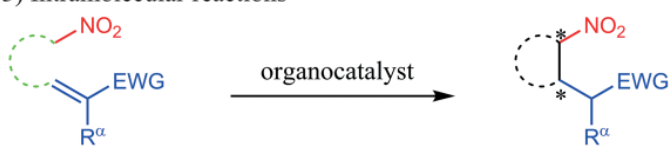

(Eq 4) Reactions with aldehydes ${ }^{[12]}$<smiles>[R]C=C(CC)C(=O)C(=O)OCC</smiles>

organocatalyst
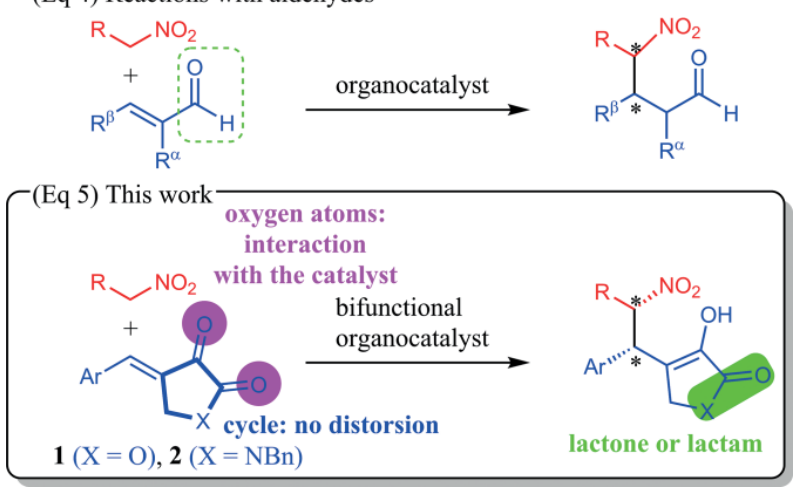
intrinsic low reactivity (Scheme 1, Equation 3). ${ }^{[1]}$ In addition to this, there are also sporadic examples of the use of highly substituted aldehydes in the presence of a chiral secondary amine, where the very strong electron-withdrawing character of the intermediate iminium ion warrants reasonable reactivity (Scheme 1, Equation 4). ${ }^{[12]}$

These three strategies bring about isolated solutions but are inherently limited in terms of potential applications. ${ }^{[13]}$ In this context, we made the hypothesis that bridging both $\alpha$ substituents could help to reduce the distortion that is responsible for the low reactivity (Scheme 1, Equation 5). Herein, we wish to disclose our results on the enantioselective Michael addition of nitroalkanes to $\beta$-arylidene- $\alpha$-ketolactones $\mathbf{1}^{[14]}$ and $\alpha$-ketolactams $\mathbf{2}^{[15]}$ catalyzed by bifunctional hydrogen-bonding catalysts. ${ }^{[4,4 g, 4 h]}$ They appeared as especially interesting candidates for enantioselective organocatalyzed Michael additions with their rigid $\alpha$-dicarbonyl structures that could be recognized by the hydrogen-bonding catalyst. ${ }^{[16]}$ The resulting Michael adducts were obtained in moderate to good yields and diastereoselectivities, but with high enantioselectivities. It should be noted that a similar reaction with only ketolactams $\mathbf{2}$ has just been reported under $\mathrm{Cu}$-catalysis. ${ }^{[17]}$

Our studies began with the reaction of $\beta$-phenylidene- $\alpha$ ketolactone $1 \mathbf{a}$ with 3 equivalents of nitromethane $(\mathbf{3 a})$ in the presence of Takemoto bifunctional $(R, R)$-thiourea I in $\mathrm{CH}_{2} \mathrm{Cl}_{2}$ at room temperature (Table 1, Entry 1). ${ }^{[4 \mathrm{e}]}$ Michael adduct 4 aa was isolated as its enol form in encouraging yield (40\%) and enantiomeric excess (84\%). Quinine-derived thiourea $\mathbf{I I}^{[4 \mathrm{~g}]}$ or squaramides III and IV $\mathbf{V}^{[\mathrm{hh}]}$ all performed less efficiently (Entries 2-4). The next idea was to change the solvent $\left(\mathrm{CHCl}_{3}\right.$, toluene, EtOAC, $\left.\mathrm{Et}_{2} \mathrm{O}, \mathrm{CH}_{3} \mathrm{CN}\right)$ and the reaction temperature $\left(-4{ }^{\circ} \mathrm{C}\right.$ or $\left.-20{ }^{\circ} \mathrm{C}\right)$, but these modifications brought about no improvement of the reaction outcome. ${ }^{[18]}$ At that point, we noticed that the expected product was accompanied by another compound $\mathbf{4 a a ^ { \prime }}$ resulting from the double Michael addition, and also extensive degradation. ${ }^{[19]}$ To try to solve these issues, we naturally attempted to increase the amount of nitromethane (3a) to outcompete the undesired pathways. Pleasingly, a gradual increase to 10 and 20 equivalents of pronucleophile improved both the yield and the enantiomeric excess, with 10 equivalents standing as the best compromise (Entries 5-7). At that point of our studies, the re-evaluation of squaramide catalyst III at $0{ }^{\circ} \mathrm{C}$ further improved the enantiomeric excess $(89 \%$ ee) at the cost of a decrease of the yield (62\%). We kept these reaction conditions as the optimized ones to continue the study (Entry 8).

A study of the reaction scope and limitations was undertaken (Table 2). $\beta$-Arylidene- $\alpha$-ketolactones $\mathbf{1} \mathbf{b}$ - $\mathbf{d}$ bearing electron-withdrawing or slightly electron-donating substituents could be combined with nitromethane (3a) to deliver products 4ab-ad in moderate yields but good enantiomeric excesses (Entries 1-3). However, it was not possible to evaluate Michael acceptors bearing more electron-donating substituents, heteroaromatics, or alkyl chains instead of the aromatic ring because they could not be prepared. On the opposite, adding substituents on the nitroalkane had a beneficial effect in the reaction outcome with $\mathbf{1} \mathbf{a}$, by increasing the stability of the resulting Michael adducts $\mathbf{4 b a - e a ~ ( E n t r i e s ~ 4 - 7 ) . ~ N i t r o e t h a n e ~ ( 3 b ) , ~ p h e n y l - ~}$
Table 1. Optimization of the reaction conditions.

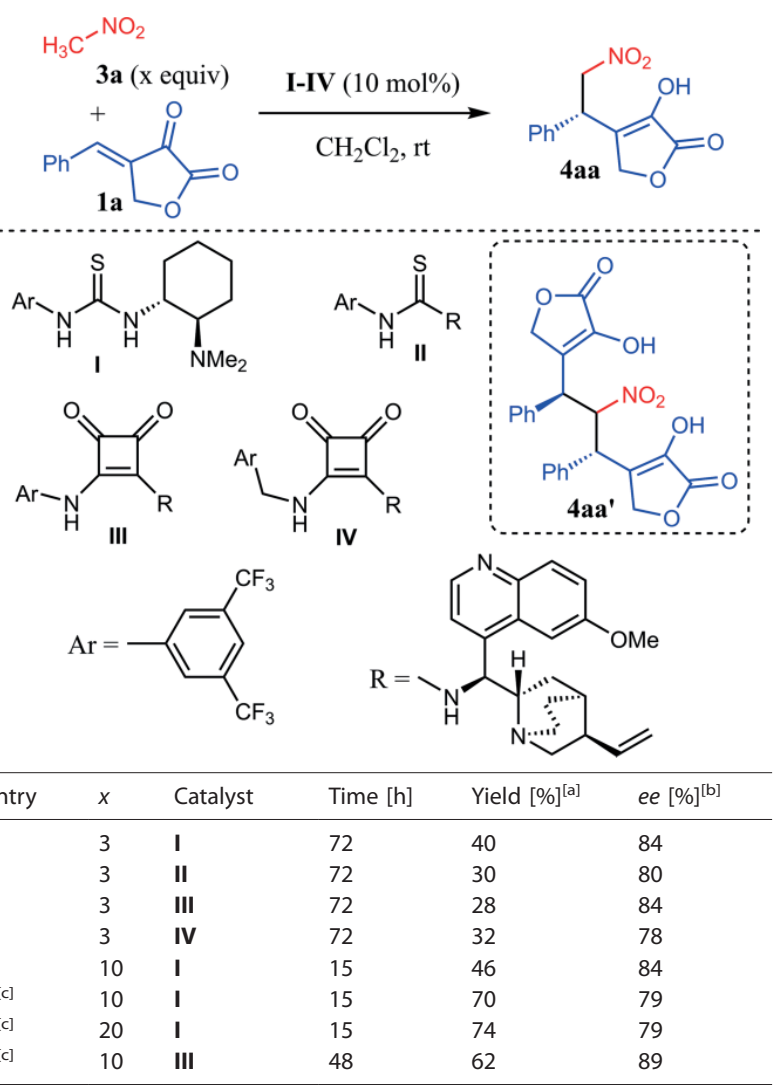

[a] Yield of analytically pure product after flash chromatography. [b] ee determined by HPLC on chiral stationary phase. [c] Reaction run at $0{ }^{\circ} \mathrm{C}$.

nitromethane $(\mathbf{3 c})$, bromonitromethane $(\mathbf{3 d})$, and ethyl nitroacetate (3e) all delivered the product with high yields. Diastereoselectivity was generally moderate, except for phenylsubstituted product 4ca (Entry 5), but enantiomeric excesses reached 82 to $90 \%{ }^{[20]}$

To try to expand the usefulness of the present transformation, we then turned our attention towards the corresponding $\beta$-arylidene- $\alpha$-ketolactams, which seems easier to prepare and use. ${ }^{[15]}$ Following the same reaction conditions, nitroalkanes $\mathbf{3 b}$-c were combined with $\beta$-arylidene- $\alpha$-ketolactams $2 \mathbf{a}-\mathbf{f}$ (Entries 8-15). Products bearing diversified functional groups were obtained in moderate to good yields, and high enantiomeric excesses between 89 and $98 \%$. Diastereoselectivities were variable from nearly no selectivity to almost complete, with an improvement when $R^{1}$ is an aromatic substituent. Additionally, comparing the optical rotation value for compound $\mathbf{5}$ ba $(-29.7$, $\left.c=1.02, \mathrm{CHCl}_{3}\right)$ with the one obtained with the Cu-catalyzed variant $\left(+31.7, c=1.02, \mathrm{CHCl}_{3}\right)$ allowed attributing the absolute and relative configurations for the products. ${ }^{[17]}$ They are also in agreement with the stereoselection model discussed at the end of the article.

Moreover, 2-nitro-1-phenylethanone (3f) could be used as a more activated pronucleophile (Scheme 2). Pleasingly, a stoichiometric amount of this compound was sufficient to promote the Michael addition to $\mathbf{1} \mathbf{a}$ and $\mathbf{2} \mathbf{a}$, followed by a C-to-O 
Table 2. Scope of the Michael addition of nitroalkanes to $\beta$-arylidene- $\alpha$-ketolactones and $\alpha$-ketolactams. ${ }^{[a]}$

$$
\mathrm{R}^{1} \mathrm{NO}_{2}
$$

3a-e (10 equiv)<smiles>[R]C=C1CC(=O)C(=O)C1=O</smiles>

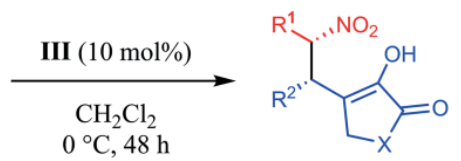

1a-d $(X=O)$

2a-f $(X=N B n)$

$0{ }^{\circ} \mathrm{C}, 48 \mathrm{~h}$

4ba-da,ab-ae $(\mathrm{X}=\mathrm{O})$ 5ba-bf,ca,cd $(X=\mathrm{NBn})$

\begin{tabular}{|c|c|c|c|}
\hline Entry & 3: $\mathrm{R}^{1}$ & 1 or $2: X, R^{2}$ & Product: yield [\%],dr, ee $[\%]^{[b]}$ \\
\hline 1 & 3a: H & 1b: $\mathrm{O}, 4-\mathrm{BrC}_{6} \mathrm{H}_{4}$ & 4ab: $61,-, 88$ \\
\hline 2 & 3a: $\mathrm{H}$ & 1c: $\mathrm{O}, 4-\mathrm{FC}_{6} \mathrm{H}_{4}$ & 4ac: $54,-, 84$ \\
\hline 3 & 3a: H & 1d: $\mathrm{O}, 4-\mathrm{MeC}_{6} \mathrm{H}_{4}$ & 4ad: $61,-, 90$ \\
\hline 4 & 3b: Me & 1a: $\mathrm{O}, \mathrm{Ph}$ & 4ba: $85,7: 1,90$ \\
\hline 5 & 3c: $\mathrm{Ph}$ & 1a: $\mathrm{O}, \mathrm{Ph}$ & 4ca: 90, 11:1, 88 \\
\hline 6 & 3d: $\mathrm{Br}$ & 1a: $\mathrm{O}, \mathrm{Ph}$ & 4da: $85,2.5: 1,82$ and 84 \\
\hline 7 & 3e: $\mathrm{CO}_{2} \mathrm{Et}$ & 1a: $\mathrm{O}, \mathrm{Ph}$ & 4ea: $80,1: 1,53$ and 53 \\
\hline 8 & 3b: Me & 2a: NBn, Ph & 5ba: $95,6: 1,97$ \\
\hline 9 & 3b: Me & 2b: NBn, $4-\mathrm{CNC}_{6} \mathrm{H}_{4}$ & 5bb: 79, 1.2:1, 98 \\
\hline 10 & 3b: Me & 2c: $\mathrm{NBn}, 4-\mathrm{NO}_{2} \mathrm{C}_{6} \mathrm{H}_{4}$ & 5bc: $89,1.6: 1,94$ \\
\hline 11 & 3b: Me & 2d: $\mathrm{NBn}, 4-\mathrm{MeOC}_{6} \mathrm{H}_{4}$ & 5bd: $85,2.2: 1,95$ \\
\hline 12 & 3b: Me & 2e: $\mathrm{NBn}, 2,4-\mathrm{Cl}_{2} \mathrm{C}_{6} \mathrm{H}_{3}$ & 5be: 95, 1.3:1, 91 \\
\hline 13 & 3b: Me & 2f: NBn, 3-thienyl & 5bf: $78,1.6: 1,93$ \\
\hline 14 & 3c: $\mathrm{Ph}$ & 2a: NBn, $\mathrm{Ph}$ & 5ca: $60,>20: 1,89$ \\
\hline 15 & 3c: $\mathrm{Ph}$ & 2d: $\mathrm{NBn}, 4-\mathrm{MeOC}_{6} \mathrm{H}_{4}$ & 5cd: $42,10: 1,90$ \\
\hline
\end{tabular}

[a] Reaction conditions: nitroalkanes $\mathbf{3 a}$-e (10 equiv.) and $\beta$-arylidene- $\alpha$-ketolactones $\mathbf{1} \mathbf{a}-\mathbf{d}$ or $\alpha$-ketolactams $\mathbf{2 a}-\mathbf{f}$ were stirred in the presence of catalys III (10 mol-\%) in $\mathrm{CH}_{2} \mathrm{Cl}_{2}$ at $0{ }^{\circ} \mathrm{C}$ for 48 hours. [b] Yield of analytically pure product after flash chromatography, $d r$ determined by ${ }^{1} \mathrm{H}$ NMR and ee determined by HPLC on chiral stationary phase, for the major diastereomer, or for each of them when possible. ${ }^{[20]}$

benzoyl migration, to deliver products $\mathbf{4 f a}$ and $\mathbf{5} \mathbf{f a}$ in high yield. Despite moderate enantioselectivities (42\% and $50 \%$ ee for $\mathbf{4 f a}$ and $\mathbf{5} \mathbf{f a}$, respectively), this observation illustrates the concept of acyl group transfer as transient activation in organocatalysis. ${ }^{[21]}$

The observed reactivity and stereoselectivity provided by the quinine-derived squaramide catalyst could be rationalized 3f (1 equiv)

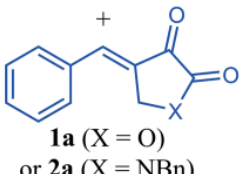

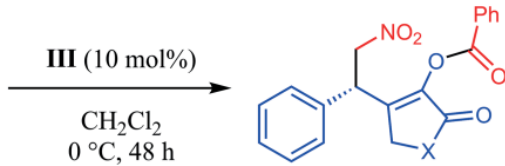

4fa $(\mathrm{X}=\mathrm{O}): 91 \%, 42 \% e e$ or $\mathbf{5 f a}(X=\mathrm{NBn}): 84 \%, 50 \%$ ee

Scheme 2. Michael additions followed by C-to-O benzoyl migrations.

based on DFT studies present in the literature, notably for related additions of nitroalkanes to enones (Figure 1). ${ }^{[22]}$ By taking inspiration directly from those precedents, we can assume that the nitroalkane interacts through double hydrogen bonding with the squaramide unit, which allows its easy deprotonation by the tertiary amine by stabilizing the nitronate ion. When an $R^{1}$ substituent is present on the pronucleophile, it is placed on the left side via an anti-gauche topology to escape from the steric hindrance of the quinuclidine bicyclic system. The resulting tertiary ammonium ion can now act as a hydrogen-bond donor to both the ketone and lactone/lactam of the electrophile to favor its approach by the lower face. The product is formed and the catalyst regenerated after $\mathrm{C}-\mathrm{C}$ bond formation, followed by proton transfer from the catalyst to the intermediate enolate ion. The application of this model from the literature is in accordance with the observed enantio- and diastereoselectivities.

In conclusion, we have developed the first organocatalyzed addition of various nitroalkanes $\mathbf{3}$ to $\beta$-arylidene- $\alpha$-ketolactones 1 and $\alpha$-ketolactams 2 . The highly functionalized products 4 and $\mathbf{5}$ were obtained with moderate to good yields and diastereocontrol, but high enantioselectivities. Moreover, the present transformation is complementary to the Cu-catalyzed variant that has just been published. ${ }^{[17]}$ Indeed, if those conditions generally allow attaining excellent diastereoselectivities,

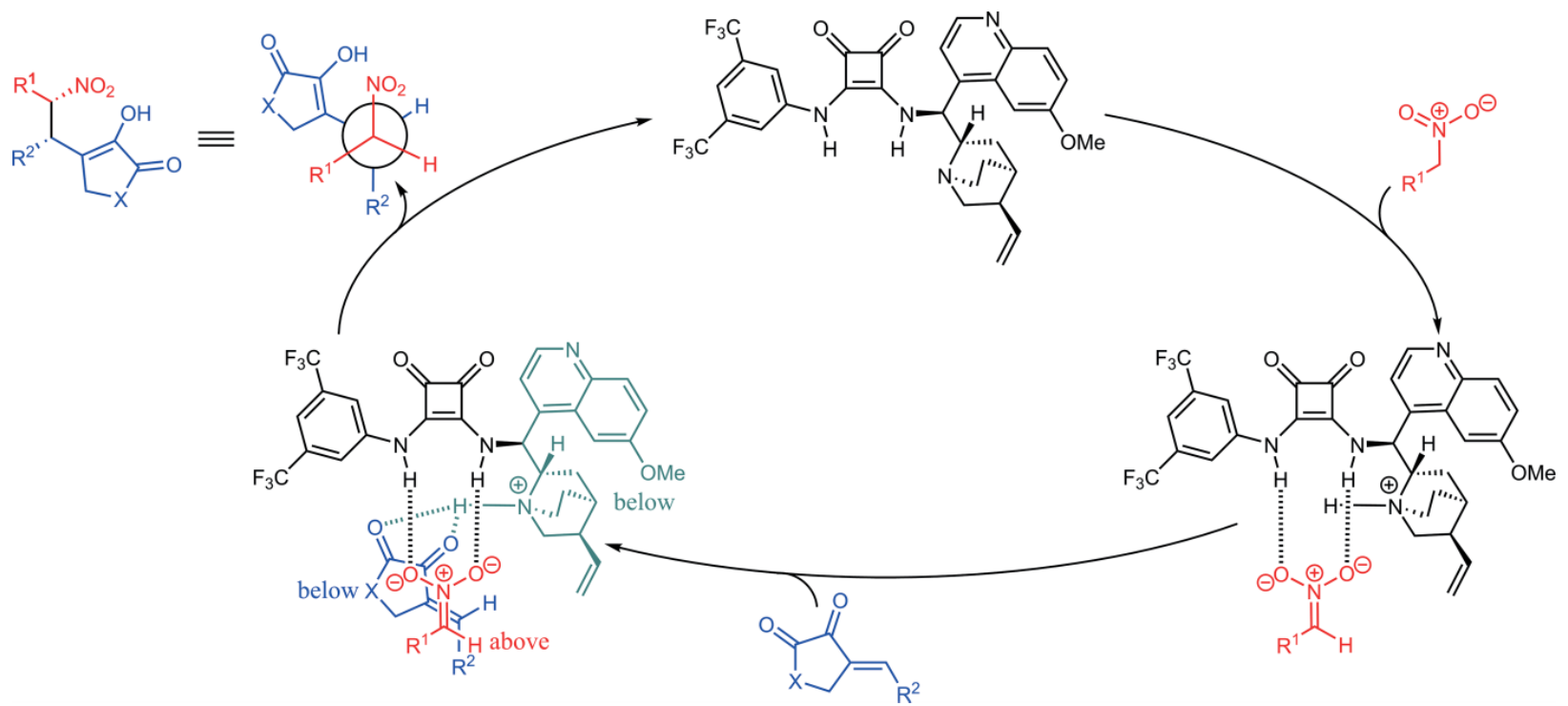

Figure 1. Reaction mechanism and rationalization of stereoselectivity. 
the applicability has been demonstrated only for lactams and with non-functionalized nitroalkanes. Therefore, the present transformation brings elements of novelty by allowing the use of lactones in the electrophilic partner, and of pronucleophilic partners bearing a bromine atom, a phenyl ring, an ester function or a benzoyl group.

\section{Acknowledgments}

We warmly thank the whole team of the Spectropole for analytical work (www.spectropole.fr), along with Dr. Nicolas Vanthuyne and Marion Jean for the HPLC analyses. Financial support from Aix Marseille Université, Centrale Marseille, the CNRS, and Université Cheikh Anta Diop de Dakar (Senegal) is acknowledged.

Keywords: Enantioselectivity · Lactams · Lactones Michael addition - Organocatalysis

[1] a) T. Komnenos, Justus Liebigs Ann. Chem. 1883, 218, 145; b) A. Michael J. Prakt. Chem. 1887, 35, 349; c) P. Perlmutter, Conjugate Addition Reactions in Organic Synthesis, Pergamon, Oxford, 1992; d) T. Tokoroyama, Eur. J. Org. Chem. 2010, 2009.

[2] a) B. List, K. Maruoka, Asymmetric Organocatalysis Thieme, Stuttgart, 2012; b) P. I. Dalko, Comprehensive Enantioselective Organocatalysis: Catalysts, Reactions, and Applications, Wiley-VCH, Weinheim, 2013; c) J. L. Vicario, D. Badia, L. Carrillo, E. Reyes, Organocatalytic Enantioselective Conjugate Addition Reactions: A Powerful Tool for the Stereocontrolled Synthesis of Complex Molecules, RSC Publishing, London, 2011.

[3] For general reviews on the reactivity of nitro compounds, see: a) N. Ono, The Nitro Group in Organic Synthesis, Wiley-VCH, Weinheim, 2001; b) R Ballini, G. Bosica, D. Fiorini, A. Palmieri, M. Petrini, Chem. Rev. 2005, 105, 933.

[4] For seminal key reports on the reactivity of nitro compounds in enantioselective organocatalysis, see: a) S. Hanessian, V. Pham, Org. Lett. 2000, 2, 2975; b) E. J. Corey, F.-Y. Zhang, Org. Lett. 2000, 2, 4257; c) N. Halland R. G. Hazell, K. A. Jørgensen, J. Org. Chem. 2002, 67, 8331; d) M. T. Allingham, A. Howard-Jones, P. J. Murphy, D. A. Thomas, P. W. R. Caulkett, Tetrahedron Lett. 2003, 44, 8677; e) T. Okino, Y. Hoashi, Y. Takemoto, J. Am. Chem. Soc. 2003, 125, 12672; f) S. B. Tsogoeva, S. B. Jagtap, Z. A. Ardemasova, V. N. Kalikhevich, Eur. J. Org. Chem. 2004, 4014; g) B. Vakulya, S. Varga, A. Csámpai, T. Soós, Org. Lett. 2005, 7, 1967; h) J. P. Malerich, K. Hagihara, V. H. Rawal, J. Am. Chem. Soc. 2008, 130, 14416.

[5] a) M. C. Kloetzel, J. Am. Chem. Soc. 1947, 69, 2271. For recent examples of post-functionalization after an organocatalyzed enantioselective step, see: b) I. Urruzuno, O. Mugica, M. Oiarbide, C. Palomo, Angew. Chem. Int. Ed. 2017, 56, 2059; Angew. Chem. 2017, 129, 2091; c) R. Ding, C. Wolf, Org. Lett. 2018, 20, 892; d) C. K. Mahato, S. Mukherjee, M. Kundu, A. Pramanik, J. Org. Chem. 2019, 84, 1053.

[6] For selected examples, see: a) M. Petrini, R. Ballini, G. Rosini, Synthesis 1987, 713; b) B. M. Trost, S. Hisaindee, Org. Lett. 2006, 8, 6003; c) S.-G. Wang, X.-J. Liu, Q.-C. Zhao, C. Zheng, S.-B. Wang, S.-L. You, Angew. Chem. Int. Ed. 2015, 54, 14929; Angew. Chem. 2015, 127, 15142.

[7] a) For example, ethyl methacrylate is 1000 times less electrophilic than ethyl acrylate: D. S. Allgäuer, H. Jangra, H. Asahara, Z. Li, Q. Chen, H. Zipse, A. R. Ofial, H. Mayr, J. Am. Chem. Soc. 2017, 139, 13318; b) J. Duschmalé, H. Wennemers, Chem. Eur. J. 2012, 18, 1111.

[8] $\alpha$ position: a) T. Ooi, S. Fujioka, K. Maruoka, J. Am. Chem. Soc. 2004, 126, 11790; b) O. Bassas, J. Huuskonen, K. Rissanen, A. M. P. Koskinen, Eur. J. Org. Chem. 2009, 1340; c) T. Inokuma, S. Sakamoto, Y. Takemoto, Synlett 2009, 1627; d) B. Zhang, L. Cai, H. Song, Z. Wang, Z. He, Adv. Synth. Catal. 2010, 352, 97; e) S. Piovesana, D. M. S. Schietroma, L. G. Tulli, M. R. Monaco, M. Bella, Chem. Commun. 2010, 46, 5160; f) M. Chiarucci, M. Lombardo, C. Trombini, A. Quintavalla, Adv. Synth. Catal. 2012, 354, 364; g) U. Das, Y.-L. Tsai, W. Lin, Org. Biomol. Chem. 2013, 11, 44; h) D. Gavin,
J. Stephens, ARKIVOC 2013, 76; i) R. Baran, E. Veverková, A. Škvorcová, R. Šebesta, Org. Biomol. Chem. 2013, 11, 7705; j) S. Hajra, S. M. Aziz, R. Maji, RSC Adv. 2013, 3, 10185; k) J. Duan, J. Cheng, P. Li, Org. Chem. Front. 2015, 2, 1048; I) Z. Bai, L. Ji, Z. Ge, X. Wang, R. Li, Org. Biomol. Chem. 2015, 13, 5363; m) M. Amireddy, K. Chen, Tetrahedron 2015, 71, 8003; n) Ż. A. Ignatiuk, M. J. Janicki, R. W. Góra, K. Konieczny, R. Kowalczyk, Adv. Synth. Catal. 2019, 361, 1108.

[9] $\beta$ position: a) S.-W. Duan, H.-H. Lu, F.-G. Zhang, J. Xuan, J.-R. Chen, W.-J. Xiao, Synthesis 2011, 1847; b) A. Quintavalla, F. Lanza, E. Montroni, M. Lombardo, C. Trombini, J. Org. Chem. 2013, 78, 12049; c) M. Monari, E. Montroni, A. Nitti, M. Lombardo, C. Trombini, A. Quintavalla, Chem. Eur. J. 2015, 21, 11038.

[10] Both $\alpha$ and $\beta$ positions: a) L. Wen, L. Yin, Q. Shen, L. Lu, ACS Catal. 2013, 3, 502; b) M. A. Horwitz, J. L. Fulton, J. S. Johnson, Org. Lett. 2017, 19, 5783.

[11] a) W. J. Nodes, D. R. Nutt, A. M. Chippindale, A. J. A. Cobb, J. Am. Chem. Soc. 2009, 131, 16016; b) W. J. Nodes, K. Shankland, S. Rajkumar, A. J. A. Cobb, Synlett 2010, 3011; c) A. Quintavalla, M. Lombardo, S. P. Sanap, C. Trombini, Adv. Synth. Catal. 2013, 355, 938; d) W. Al-Ani, K. Shankland, A. J. A. Cobb, Synlett 2016, 27, 17.

[12] a) J.-m. Zhang, C.-I. Lou, Z.-p. Hu, M. Yan, ARKIVOC 2009, 362; b) L. Guo, W. Zhang, I. A. Guzei, L. C. Spencer, S. H. Gellman, Org. Lett. 2012, 14, 2582; c) F. Malihi, D. L. J. Clive, C.-C. Chang, Minaruzzaman, J. Org. Chem. 2013, 78, 996; d) M. W. Giuliano, S. J. Maynard, A. M. Almeida, A. G. Reidenbach, L. Guo, E. C. Ulrich, I. A. Guzei, S. H. Gellman, J. Org. Chem. 2013, 78, 12351; e) M. W. Giuliano, S. J. Maynard, A. M. Almeida, L. Guo, I. A. Guzei, L. C. Spencer, S. H. Gellman, J. Am. Chem. Soc. 2014, 136, 15046; f) L. Bernardi, M. Fochi, R. Carbone, A. Martinelli, M. E. Fox, C. J. Cobley, B. Kandagatla, S. Oruganti, V. H. Dahanukar, A. Carlone, Chem. Eur. J. 2015, 21, 19208.

[13] There is also a single report of cyclopropanation between bromocyclopropane and trisubstituted Michael acceptors with only one activating group: B.-L. Zhao, D.-M. Du, Eur. J. Org. Chem. 2015, 5350.

[14] a) For their preparation, see supporting information; b) no catalytic enantioselective reaction has been reported with those substrates and there is only a single example of Michael addition in the racemic series: K. Matsuo, M. Adachi, T. Takagi, S. Ueno, T. Arase, F. Kuroi, Heterocycles 2005, 65, 377.

[15] a) For their preparation, see supporting information. A handful of catalytic enantioselective domino processes are known with those substrates. See: b) S. Zhang, Y.-C. Luo, X.-Q. Hu, Z.-Y. Wang, Y.-M. Liang, P.-F. $\mathrm{Xu}$, J. Org. Chem. 2015, 80, 7288; c) Y. Lu, Y. Zhou, L. Lin, H. Zheng, K. Fu, X. Liu, X. Feng, Chem. Commun. 2016, 52, 8255; d) J.-L. Li, K.-C. Yang, Y. Li, Q. Li, H.-P. Zhu, B. Han, C. Peng, Y.-G. Zhi, X.-J. Gou, Chem. Commun. 2016, 52, 10617; e) C. Wang, H. Jia, C. Zhang, Z. Gao, L. Zhou, C. Yuan, Y. Xiao, H. Guo, J. Org. Chem. 2017, 82, 633; f) J.-L. Li, L. Fu, J. Wu, K.-C. Yang, Q.-Z. Li, X.-J. Gou, C. Peng, B. Han, X.-D. Shen, Chem. Commun. 2017, 53, 6875; g) Q. Li, L. Zhou, X.-D. Shen, K.-C. Yang, X. Zhang, Q.-S. Dai, H.-J. Leng, Q.-Z. Li, J.-L. Li, Angew. Chem. Int. Ed. 2018, 57, 1913; Angew. Chem. 2018, 130, 1931; h) Q.-Z. Li, Y. Liu, H.-J. Leng, J.-L. Li, Synlett 2018, 29, 2601; i) Y. Wang, Y. Chen, X. Li, Y. Mao, W. Chen, R. Zhan, H. Huang, Org. Biomol. Chem. 2019, 17, 3945; j) X. Lu, Y. Zhang, Y. Wang, Y. Chen, W. Chen, R. Zhan, J. C. G. Zhao, H. Huang, Adv. Synth. Catal. 2019, 361, 3234; k) X. Zhao, J. Xiong, J. An, J. Yu, L. Zhu, X. Feng, X. Jiang, Org. Chem. Front. 2019, 6, 1989.

[16] For the use of $\alpha$-dicarbonyl compounds as pronucleophiles in organocatalysis, see: a) O. Baslé, W. Raimondi, M. M. Sanchez Duque, D. Bonne, T. Constantieux, J. Rodriguez, Org. Lett. 2010, 12, 5246; b) W. Raimondi, D. Bonne, J. Rodriguez, Angew. Chem. Int. Ed. 2012, 51, 40; Angew. Chem. 2012, 124, 40; c) W. Raimondi, O. Baslé, T. Constantieux, D. Bonne, J. Rodriguez, Adv. Synth. Catal. 2012, 354, 563; d) W. Raimondi, D. Bonne, J. Rodriguez, Chem. Commun. 2012, 48, 6763.

[17] a) The complementary Cu-catalyzed alternative conditions were reported during the preparation of our manuscript: Y. Huang, Z. Zha, Z. Wang, Org. Lett. 2020, DOI: https://doi.org/10.1021/acs.orglett.0c00030; for other metal-catalyzed transformations on the same substrates, see:; b) X. Hu, Y. Zhou, Y. Lu, S. Zou, L. Lin, X. Liu, X. Feng, J. Org. Chem. 2018, 83,8679 ; c) Y. Huang, Y. Li, J. Sun, J. Li, Z. Zha, Z. Wang, J. Org. Chem. 2018, 83, 8464.

[18] See supporting information for further details. 
[19] Even though no experimental proof could be collected, it is likely that the product 4aa exhibits intramolecular hydrogen-bonding between the enol function and the nitro group. This intramolecular activation could explain why the double addition product $\mathbf{4} \mathbf{a a}^{\prime}$ is observed even in the presence of a large excess of nitromethane:

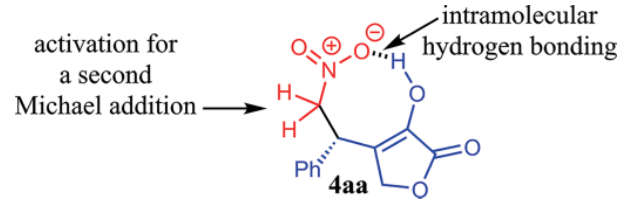

[20] For the examples where the enantiomeric excesses were determined for both diastereomers, values are very similar (Table 2, Entries 6 and 7). This observation points towards an epimerization at the position $\alpha$ to the nitro group in the basic reaction conditions.

[21] a) For a review, see: J. Rodriguez, A. Quintard, Synthesis 2019, 51, 1923; for recent related example, see: b) K. Mondal, S. C. Pan, J. Org. Chem. 2018, 83, 5301; c) Y.-X. Song, D.-M. Du, Adv. Synth. Catal. 2019, 361, 5042.

[22] a) B. Kótai, G. Kardos, A. Hamza, V. Farkas, I. Pápai, T. Soós, Chem. Eur. J. 2014, 20, 5631; b) M. N. Grayson, J. Org. Chem. 2017, 82, 4396. 